\title{
Islamophobia as an Antithesis of Western Hegemony in John Updike's Terrorist
}

\author{
Saad Abd Saadoon ${ }^{1}$, Dr. Wan Mazlini Othman ${ }^{2}$
}

${ }^{1} \mathrm{Ph}$. D. Student in Literature, Faculty of Languages and Communication, University Pendidikan Sultan Idris, Kula Lumpur, Malaysia

${ }^{2}$ Dr, Faculty of Languages and Communication, University Pendidikan Sultan Idris, Tg. Malim Perak, Malaysia

\begin{abstract}
This paper examines islamophobia in John Updike's Terrorist. The study will mainly focus on the ideological confrontation between the East and The West. The traditional relationship between the East and the West is based in the Western perception of the East as the subordinate other. The West itself is the dominant self. However, the East rejects the Western hegemony. It begins to affirm its identity to emulate the Western dominance. The study is going to analyze the East's response to the West through resistant violence. They Eastern, or oriental, fanatics try to prove their existence in the world, especially the United States of America. As a result, the practice extreme actions in the American societies. The study will identify this religious extremism as the main cause of islamophobia that started to be present in the American societies at the beginning of the twenty-first century. Therefore, Edward Said's concept of self-other relationship will be applied to interpret the ideological confrontation between the East and the West. Such confrontation is going to be analyzed to explore neo-orientalism depicted in the novel. That is, the Eastern refusal of the Western hegemony results in parallel power. This power sustains the extremists' opposition of the West. Thus, the study will unravel neo-orientalism as the result of the opposing powers of the West and the East.
\end{abstract}

Keywords - Identity, Islamophobia, Neo-Orientalism, Orientalism, Self-Other Relationship, Updike.

\section{INTRODUCTION}

This study will analyze Updike's Terrorist form an oriental perspective. The discussion of the oriental elements in the novel will depend on the representation of the East and the West in the course of the novel's plot. In this regard, three pertinent concepts will be applied. They are Said's concept of self-other relationship, the concept of hegemony and the concept of islamophobia. The study will first analyze the self-other relationship; and this relationship will be specified as a connection between the East and the West depicted in the novel. Then, it will tackle the representations of hegemony. This hegemony solely entails the West, as a hegemony power, and the East as a colonized ethnic entity. This ideological encounter, ultimately, is going to be interpreted as a premise for the emancipation of the notion of islamophobia. Therefore, the notion of islamophobia will be discussed by applying the concept of ambivalence. Thus, islamophobia is going to be argued as the main cause of new orientalism.

\section{SELF-OTHER RELATIONSHIP}

Updike's Terrorist tells the story of Ahmad, a student who repeatedly quarrels with other boys, like Tylenol regarding his girlfriend Joryleen. He has erotic desires towards Joryleen; but controls his desires. The impetus of this control is ascribed to his spiritual resort to the recitation of Qur'an and God's moral instruction under the supervision of his imam Shaikh Rashid. He appears to be greatly influenced by the imam's religious teachings that depend on the Prophet traditions. The imam is very different form Ahmad's school counselor, Jack Levy. The imam and Jack represent two incongruent ways of life. The novel is predominantly about Islamic teachings and the western lifestyles. The protagonist, Ahmad, is torn between these emblematic cultural variations. Updike chooses Paterson, New Jersey, as the novel's regional setting holds collateral compatibilities of these cultural varsities.

The issue of self-other relationship is sustained with the issue of power in Updike's writings. He portrays the colonial power that is used to construct hegemony over the colonized people. The colonial powers do not leave the colonized people alone. They are exploited in an inhuman 
manner. They do not have any chance to build their own nation. They are completely restricted by the colonial power. In this regard, hegemony is the most detrimental factor of hindering the stability of the colonized people's lives. Colonial hegemony restrains the colonized peoples' subjective authority over their own national territories (Said, 2016). Updike attends to this notion in the bulk of his fictional writings. In Updike's Terrorist, the self-other relationship is evident in the perception of Islam in the introductory paragraphs of the novel: "The student's faith exceeds the master's; it frightens Shaikh Rashid to be riding the winged white steed of Islam, its irresistible onrushing. He seeks to soften the Prophet's words, to make them blend with human reason, but they were not meant to blend: they invade our human softness like a sword. Allah is sublime beyond all particulars. There is no God but He, the Living, the Self-Subsistent; He is the light by which the sun looks black" (p.5).

Orientalism, thus, causes psychological sufferings for the colonized people. These sufferings take the shape of internal and external representations (Sicherman,1990). The internal representation of colonialism sis their psychic influences; and the external representation is the physical sufferings. Both exemplify the negative practices of colonialism (Said,1979). The internal representation of power makes the colonized people suffer from psychic complexities. They do not have a sense of belonging to their faith. They lack the resisting power. They are interrupted by the colonial hegemony. The colonized people are not as equal as their colonial westerns. As a reaction, the colonized people need psychic compensation. They use their own ability to oppose colonialism. This is the core of the internal representation of colonialism. The colonized people develop psychic problems which culminate in their psyches and do not have outlets for their dilemmas. Updike reflects such problems in his Terrorist in an oriental sense. The longinherited dichotomy between the east and the west is a recurrent token of his fictional scenes, like the advent of Islam in the western lands: "Look how Christianity committed genocide on the Native Americans and undermined Asia and Africa and now is coming after Islam, with everything in Washington run by the Jews to keep themselves in Palestine" (p.21).

Updike, furthermore, tackles the issue of colonial power in his works. His plays parade the nexus of colonial power. The external representation of colonial power is the physical sufferings. The colonized people are tormented by the colonizers. They are exploited for ideological concerns.
They do not have any choice to be free of this torture. The western colonial masters do not allow them to be free. The colonized people, here, undergo pain and sufferings in terms of self-other relationship. They are both psychically and physically suffering. These sufferings leave their apparent impact upon their individuality. They lose their confidence in their ideological ideals because they do not have the resisting power. Updike, in Terrorist, presents this power in a weak position. The colonized Muslims are subjugated for ideological concerns. Consequently, all what they think is to get rid of this daunting faithful ideology. They do not invent resistant strategies to cancel their colonial treatment. They lose integral human features: "There is nothing in Islam to forbid watching television and attending the cinema, though in fact it is all so saturated in despair and unbelief as to repel my interest. Nor does Islam forbid consorting with the opposite sex, if strict prohibitions are observed" (p.38).

Identity is one of the human features that Updike deals with in Terrorist. The loss of identity belittles the Muslims' ability to be equal to their colonial counterpart. They are "relative" to their colonial masters. Here, the word relative means dependent; that is, the colonized Muslims become dependent on their white colonizers. They are not able to depend on themselves to get rid of their colonial presence over their lands (Said,1979). Updike portrays the issue of identity in a terrorist context. Identity is one of the most complicated issues since the start of orientalism. The issue of identity paves the way for other issues, like Islamic extremism treated in Updike's novel: "My teacher at the mosque thinks that the dark-eyed virgins are symbolic of a bliss one cannot imagine without concrete images. It is typical of the sex-obsessed West that it has seized upon that image, and ridicules Islam because of it" (p.39).

One apparent issue in oriental writings is identity. Abdalhadi Abu Jweid (2016) argues that identity and its narrative dimensions are used as survival strategies. It is utilized as a way of obliterating colonialism and the colonial enterprises. Identity includes the depiction supernatural elements that defy common sense. It does not undergo the laws of nature. The postcolonial appropriation of identity is to reject colonialism in a form of non-military contact. Identity is the proper tool to encounter colonial events and how to underscore the national sense of belonging and selfother relationship. It is concerned with the narrative depiction of survival (Sutphen, 2015). The oppressed people seek refuge of colonialism through identity. This is due to their lack of ability to accept colonialism as reality. Identity, 
at this point, serves as a vehicle of empowerment. The oppressed people are empowered with identity. Yet, the author is the ideational creator of this empowerment. The fictional characters are empowered with identity by the author who also tries to reject colonial hegemony. In Updike's Terrorist, the oppressed Muslims seek refuge from oppression through Islamic teachings: "It seemed to Ahmad that, as with the facts of Paradise, his teacher resorted to metaphor as a shield against reality. Joryleen, though an unbeliever, did have feelings; they were there in how she sang, and how the other unbelievers responded to the singing. But it was not Ahmad's role to argue; it was his to learn, to submit to his own place in Islam's vast structure, visible and invisible" (p.42).

Post-colonialism uses identity simultaneously with the repetitive narrative moments. It is used in this fictional fashion to render the characters special from of empowerment (Sutphen,2015). By using identity, the characters could escape their negative destiny. This destiny could be the colonial ideology. Colonialism might be resisted by utilizing repetitive narrative structuring. This structuring is saturated with identity in all fictional moments. As such, the narrative repetitive structuring is the authorial reflection in the plot. Orientalism, similarly, utilizes identity as a decisive agent against colonialism. When the enslaved people are presented in colonial atmospheres, they might be portrayed in slavery places (Said,1979). Updike's, in Terrorist, tackles the same issue by depicting the Islamic responses in the plot: "Levy merely nods, letting this now-cocky woman run on. What she might tell him about Ahmad could be a help.... My son is above it all," she states. "He believes in the Islamic God, and in what the Koran tells him. I can't, of course, but I've never tried to undermine his faith. To someone without much of one, who dropped out of die Catholic package when she was sixteen, his faith seems rather beautiful" (p.47).

Oriental identity accentuates memory as the site where identity and the pertinent moments might take place. These moments are characterized by phantoms or ghosts that appear to the main characters (Lucas,2006). The characters use their identity al power or identity in all situations, to express their ability to be free of hegemony and its relative sequences in the light of self-other relationship. The colonial apparitions accompany the identity al moments in the narrative structuring. Here, post-colonialism renders the implications of the concept of identity in the larger context of post-colonialism. Consequently, identity could be applied to analyze all fictional genres within colonial discourse (Said 1979). Yet, identity emphasizes another colonial issue. In Terrorist, Updike appropriates the same notion by portraying the sense of extreme Islamic ideologies: "Islam meant nothing to me-less than nothing, to be accurate: it had a negative rating. And it meant not much more to his father. Omar never went to a mosque that I could see, and whenever I'd try to raise the subject he'd clam up, and look sore, as if I was pushing in where I had no business" (p.47). Self-other relationship is the tangible exemplification of colonial hegemony. Post-colonialism has an implicit voice that tries to reject ideological segregation against the colonized people. Self-other relationship leaves psychological harmful memories in the colonized people's experiences (Said,1979). They become a victim for their conditions under hegemony. self-other relationship, therefore, does not make them normal human beings. These are the general features of Updike's Terrorist: "For four or so blocks to the west, the so-called Arab section, begun with the Turks and Syrians who worked as tanners and dyers in the old mills, stretches along this part of Main Street, but Ahmad never ventures there; his exploration of his Islamic identity ends at the mosque. The mosque took him in as a child of eleven; it let him be born again" (p.55). Cultural conflict is deemed one conspicuous token of selfother relationship writing styles in postcolonial works. It addresses the complexities of colonial times with meticulous expressions conveyed by fictional quasi-real stories. Orientalism, accordingly, has diverse writing styles. It deals with real and imaginative settings that resemble the experiences of real people. These are delivered in fictional writings. In like manner, postcolonial critics are attentive to a kind fiction produced by the colonial authority and literary works(Langfur, 2006). Post-colonialism is a prime representative of this kind. Consequently, postcolonial criticism is concerned with the function of the western literary canon and the history of western as prevalent types of post-colonialism (Said,1979). Updike tackles these ideas by approaching the essences of identity in Terrorist: "The Black Muslims of New Prospect, and the apostate adherents of the Nation of Islam, keep to their own lofts and storefront sanctuaries. Shaikh Rashid's hope of starting, in one of his third-floor spaces, a kuttab for teaching the Qur'an to flocks of elementary-school-age children, hangs short of fulfillment. Lessons that Ahmad seven years ago began in the company of eight or so others, in age from nine to thirteen, are now carried on by him as the only pupil" (p.56). 
In the new land the individuals compare themselves to the original people who look at them in disdain and compassion. So, when they judge those ideological people, they regard them as being different (Said,1979). This is the essence of the concept of self-other relationship which is often inherent in ideological communities. Additionally, the meaning of ideological double consciousness is a double hesitation concerning the belonging to the ancestral home. Updike treats this ideological peculiarity via the notion of Islamic thought that plays an integral role in shaping new cultural identities in the novel: "He [Ahmad] is alone with the teacher, whose soft voice in any case carries best to a small audience. Ahmad is not utterly comfortable with his master, but, as the Qur'an and the Hadith enjoin, reveres him" (p.56).

The concept of self-other relationship in the oriental discourse of identity exemplifies the awareness of belonging to discrepant cultures in Updike's Terrorist. The minority through the oriental discourse feels itself as having no genuine self-esteem and views itself through the construction of the self in the new world. Thus, the disowned people experience a fractured sense-of-self because it has sunken in the host culture that is different from the original national identity and socio-cultural beliefs. Oriental discourse tries to keep these beliefs as parts of the original traditions that are devastated by colonialism and sustained by some Muslim people who do not lose the sense of belonging to homeland: "For seven years Ahmad has been coming twice a week, for an hour and a half, to learn the Qur'an, but he lacks opportunity in die rest of his time to use classical Arabic. The eloquent language, al-lugha alfusbd, still sits awkwardly in his mouth, with all its throat syllables and dotted emphatic consonants, and baffles his eyes: the cursive print, with its attendant spattering of diacritical marks, looks small to him, and to read it from right to left still entails a switch of gears in his head" (p.56). Themes of interconnectedness, hegemony, homeliness, and alienation are the colonial body that emerges out of the colonized people's difficulty for the purpose of differentiating their sense-of-self-identity in postcolonialism's writing styles (Flores,2000). This is because they are deep rooted in a certain place. In reference to the last point, the oriental discourse of identity is relevant to an awareness of orientalism as well as an issue of multi-local supplement. Therefore, orientalism represents the image struggle for those who are expelled from the status of settlement (Said,1979). In other words, the image of cultural politics that locates its objectives against nationalism and assimilation is considered within colonial awareness of selfother relationship (p.104). In Terrorist, Updike portrays the self-other relationship via the Muslim characters: "It was Islam, Shaikh Rashid had more than once explained, that had preserved the science and simple mechanisms of the Greeks when all Christian Europe had in its barbarism forgotten such things. In today's world, the heroes of Islamic resistance to the Great Satan were former doctors and engineers, adepts in the use of such machines as computers and airplanes and roadside bombs" (p.77).

Orientalism and identity, therefore, are considered as the most important feature in Updike's novel. This is because the colonized Muslims' existence depends on the formation of its identity and the way it searches to achieve and establish their identity. There is no factual methodology to construct the national identity since there is no real threat behind the ability to formulate any kind of identity autonomy. The colonizer (the west), therefore, is studied from the negative aspect of the colonial human perspectives. It does not cope with any necessary change as the surroundings around it change and transform rapidly. The colonizer does not also have the potential to present itself on the position of a powerful entity which can forge its existence and presence in life as other entities (Said 58). It is surrounded by its traditional conventions and traditions which have no any indication of realty or the pursuit of life. Updike attends to this notion through ideological faith: "Islam, unlike Christianity, has no fear of scientific truth. Allah had formed the physical world, and all its devices when put to holy use were holy. Thus Ahmad, with such reflections, received his truckers' license. Class $\mathrm{C}$ required no road test. Shaikh Rashid is pleased" (p.77).

\section{HEGEMONY AS AN IDEOLOGICAL CONCEPT}

The colonizer, in orientalism, is studied in terms of powerful hegemonic entity. It has the possible qualities to subjugate and suppress the colonized (Karlsen,1987). At the onset of the relationship between the colonized and the colonizer, there is no equality. There is no even any degree of similarity or discrepancy. The colonizers have a powerful hegemony enables them to utilize the colonized people to the limits. The colonizer hegemony practices different methods to improve its power and sustain its ability to continue surviving over the colonized. It uses the colonial power to settle in the colonized land and traditional territories. In this way, the colonizer establishes its power against the colonized poor cultural backgrounds. The 
colonizers used may agendas to procreate its permanent existence in the colonized lands. It uses religion as a means of attracting the colonized to the theological teachings and traditions which may improve the lives of the colonized. The same religious insights are evident in Updike's Terrorist: "He [Shaikh Rashid] tells Ahmad, 'Appearances can deceive. Though I know our mosque appears, to youthful eyes, shabby and fragile in its external trappings, it is woven of tenacious strands and built upon truths set deep in the hearts of men. The mosque has friends, friends as powerful as they are pious" (p.77).

Once the colonized people accept the colonizer's hegemony and culture, it will proceed developing and it will become adherent to the colonizers' teachings (Karlsen,1987). The religious factor is one of the most successful procedures used by the colonizer to attract the colonized. This is because if the colonized convert to a new religion, it will consequently accept the cultural traditions of the colonizer. These cultural traditions change the human perspective of the colonized. Consequently, the colonized become more familiar with the traditional customs and conventions of the colonizer. It will begin developing an intimate relationship with the colonizer. In this sense, both the colonized and the colonizer benefit from each other. However, the colonizer does not make any benefit because it does not need $t$ establish its identity. The colonized benefits from this relationship because it develops its identity. But this identity is not autonomous. It is developed out of the colonizer's power. In Updike's Terrorist, Islam is depicted in similar manner: "before Islam rendered him immune, a long-coveted electronic game obsolete within a season, die motlier and son were besieged on all sides by attractive, ingenious things they didn't need and could not afford, potential possessions that other Americans seemed to acquire without effort but that for them were impossible to squeeze from the salary of a husbandless nurse's aide. Ahmad tasted American plenty by licking its underside" (p.83).

Identity ambivalence is another conspicuous feature of hegemony (Shaffer,2007). As the term suggests, hegemony requires two sides. Such binary hegemony is present in the majority of post-colonialism discourses. The internal structure of identity's narrative explores the congruent relationship between the colonized people and identity.The thematic representations of identity and orientalism that is relative to the postcolonial qualities in the bulk of postcolonial writings. The themes of colonialism and identity take the shape of ambivalence; whereby the relationship between the colonized people and their oppressor comes into the scene. In this regard, postcolonialism is highly concerned with the intrinsic mechanism of colonial fiction for the sake of discovering the narrative devices of fictional works(Shaffer, 2007). Updike conveys this argument in terms of the Islamic representations in Terrorist: "They have a kind of network; I don't know how much the Islamic thing matters. Most of their customers around New Prospect are black families. Some of their homes, Ahmad says, are surprisingly nice. He loves seeing the different areas, the different lifestyles" (p.92).

Orientalism has a highly appreciated narrative style that addresses crucial issues in fictional modes. These issues are mainly related to the cultural ideology that is considered the authentic fictionalization of the identity formation experiences. In essence, the cultural memory is the racism and is relative problems. The cultural memory is the racial memory per se; and it comes out in the form of narrative materiality. The fact that cultural ideology corresponds to the hegemonic ideology goes along with the historical materiality of communities portrayed in colonial works. The historical dimensions of the formation of identity are handed down in different forms of verbal historical and colonial perspectives (Shaffer, 2007). In Updike's Terrorist, the ideological hegemony is portrayed in the light of Islam and the west: "There is no ummah here, both Charlie and Shaikh Rashid point out-no encompassing structure of divine law that brings men rich and poor to bow down shoulder to shoulder, no code of self-sacrifice, no exalted submission such as lies at the heart of Islam" (p.92).

The concept of hegemony delineates the radical differences between the cultural ideology and racial hegemony. These differences are measured by the multicultural claims; whereby citizens can affirm their ethnical roots in the context of cultural history regarding identity and ethnicity. Accordingly, ethnicity is superior to race in the cultural history because ethnicity is an inherited trait rather than a biological one. Yet, this fact sharply contradicts with the appreciation of race as an equal trait among all ethnical groups. Therefore, post-colonial works deal with various cultural issues that are projected in colonial works. These works have a universal appeal as they reveal the most critical moments of colonized people's needs to be equal in stable communities. In this respect, the cultural memory mingles with individual awareness to complete the necessity of individual pursuits of identity (Paquet, 2002). Such, ethnic groups are classified as the east and the west in 
Updike's Terrorist: "Ahmad sometimes has to suppress a suspicion tJiat his teacher inhabits a semi-real world of pure words and most loves the Holy Qur'an for its language, a shell of violent shorthand whose content is its syllables, the ecstatic flow of "l"s and "a"s and guttural catches in the throat, savoring of the cries and the gallantry of mounted robed warriors under the cloudless sky of Arabia Deserta" (p.92).

Hegemony exemplifies the threat of gaining identity since it supports the existence of collective experience at the expense of individual consciousness of the west. Being so, orientalism furnishes fiction with these cultural facts to expose the meticulous fabrication of communities and their individuals' quest to gain identity. In sum, the cultural hegemony is a remedial mode of reminiscences. It is the self-centered idealization that claims to regain the impossible (Paquet, 2002). In Updike's Terrorist, this ideological hegemony is conveyed by depicting the invasion of some Muslim countries that represent the true threat of the American hegemony:

Not so,' Ahmad says. He did not hear in Charlie's gruff response the quaver of doubt, the silken shimmer of irony, which he detects in the voice of Shaikh Rashid. Charlie is a man of the world, but Islam is solidly part of that world. Lebanese are not fine-honed and two-edged like Yemenis or handsome and vanishing like Egyptians. He shyly points out, 'Already I have lived longer than many martyrs in Iran and Iraq.' (p.96)

Oriental writings focus on colonialism and its relative issues. It deals with the colonial subjects that influence the world since the beginning of colonialism up to the present day. In colonial fiction, post-colonialism depicts many thematic issues that have a universal appeal. One of these issues is color. This is issue is of paramount importance since it relates to the treatment of colonized people in different ways. Before the mid-twentieth century, hegemony was a great subject to the public opinion in all over the world (Ray,2015). It is also conspicuous in Updike's Terrorist:

Here those awaiting delivery tend to live: darker-skinned families with voices and televisions sounding from back rooms, out of sight, as if chamber after chamber of linked family members telescope out from the vestibule. Sometimes there are signs of Islamic practice - prayer mats, women in hijabs, framed images of the twelve imams including the Hidden Imam with his featureless face, identifying the household as Shia. (p.97)
The concept of hegemony is sustained with the issue of colonial power in post-colonialism writings. Postcolonialism portrays the colonial power that is used to construct hegemony over the colonized people (Ray,2015). This is the core of the internal representation of colonialism. Such opposition comes out of religious faith in Updike's Terrorist: "Ahmad feels his pride of isolation and willed identity to be threatened by the masses of ordinary, hardpressed men and plain, practical women who are enrolled in Islam as a lazy matter of etlinic identity. Though he was not the only Muslim believer at Central High, there were no others quite like him —of mixed parentage and still fervent in tlie faith, a faith chosen rather than merely inherited from a father present to reinforce fidelity" (p.97).

Post-colonialism accentuates hegemony as the site where colonial moments might take place. These moments are characterized by crusades that appear to the main fictional plots. The characters use their ideological power, or ethnic situations, to express their ability to be free of colonialism and its relative sequences. In Updike's Terrorist, the hegemonic power comprises both the American crusades against Islam and the Muslim people portrayed in the novel: "The Hydra," Ahmad says, to show he is not completely ignorant. The image recurs in Shaikh Rashid's sermons, in illustration of the futility of America's crusade against Islam, and was first encountered by Ahmad in watching children's television, the cartoons on Saturday mornings, while his mother slept late" (p.100). Colonial oppression results in drastic changes in the colonized people's ideology. These people do not accept the change since they need to maintain their original ethnicity. As a result, they prevent their socio-cultural traditions through resistance. Resistance ultimately leads to their independence and liberty. In Updike's Terrorist, the critical implications of hegemony are carried out via the ideological conflict between some Muslims and the West:

Ahmad knows, from Shaikh Rashid's dry, half-smiling allusions, of the Sufi enthusiasm and rapture that had anciently afflicted Islam, but finds not even a faint echo of it in the Islamic channels beamed from Manhattan and Jersey City - just the five calls to prayer broadcast over a still slide of the great mosque of Mohammed Ali in Saladin's Citadel, and solemn panels of bespectacled professors and mullahs discussing the anti-Islamic fury that has perversely possessed the present-day West, and sermons delivered by a turbanned 
imam seated at a bare table, relayed by a static camera from a studio strictly devoid of images. (p.108)

Colonial resistance involves the attempt to obliterate hegemony. It takes different shapes during the colonial encounters between the suppressed people and their oppressive colonizers. Colonial resistance is considered as the most appropriate means of eliminating colonialism and its destructive agendas. Colonialism brings about negative influences upon the socio-cultural traditions of the colonized people. Consequently, the colonized people tend to obliterate colonialism in order to gain their cultural residuals before the advent of colonialism. The long colonial periods make the oppressed people feel that they need liberty and national progress in all life's aspects. As such, they begin to find suitable exists for the oppression imposed over them. The resistance tools vary and differ from each other (Aulette,2017). In Updike's Terrorist, such hegemony includes Islam in opposition to the West that hosts several religious backgrounds, like Judaism and Christianity:

They believe that something can be done. That the Muslim peasant in Mindanao need not starve, that the Bangladeshi child need not drown, that the Egyptian villager need not go blind with schistosomiasis, that the Palestinians need not be strafed by Israeli helicopters, that the faithful need not eat the sand and camel dung of the world while the Great Satan grows fat on sugar and pork and underpriced petroleum. They believe that a billion followers of Islam need not have their eyes and ears and souls corrupted by the poisonous entertainments of Hollywood and a ruthless economic imperialism whose Christian-Jewish God is a decrepit idol, a mere mask concealing the despair of adieists. (p.108)

One of the most conspicuous means of resisting hegemony is rebellion. It enables the oppressed people to get rid of colonialism. Resisting colonialism comes in the form of rebellion when the exploited minorities need to be independent. They try to seek self-autonomy since they long for equality and liberty. Consequently, the colonized people begin to plot against their colonizers by planning authentic tactics to achieve their independence goals. The process of plotting against the colonizers is often argued as "conspiracy"; whereby the colonized people reach their aims by rejecting colonialism through resistance (Aulette, 2017). Similarly, this conspiracy is held by the Islamic oriental image in the Updike's Terrorist: "His lips move an inch from her forehead. He has decided to be open witii her, about this thing in his life that his instinct is to protect from everyone, even from Charlie, even from Shaikh Rashid. 'I still hold to the Straight Path,' he tells Joryleen. 'Islam is still my comfort and guide. But-" (p.124). The resistance of this hegemony corresponds to the notion of islamophobia. The following section will discuss the representations of islamophobia in Updike's Terrorist.

\section{ISLAMOPHOBIA AND THE CONCEPT OF AMBIVALENCE}

As I have argued, colonial rebellion comprises the notion of conspiracy when colonialism is gradually destructed by the will of the colonized people. In this regard, rebellion includes uprising and demonstration against the unjust colonial practices. These are forms of expressions representing the need for independence. However, the colonizers exert hegemony and power in the course of colonial rebellion. Consequently, a sense of violence springs out of such tumultuous times because both the colonized and the colonizer meet each other in the same colonial peripheries (Aulette, 2017). Such fatal encounters are motivated by the feelings of superiority and inferiority; whereby the West believes that they are superior to the East that seek to get rid of inferiority complex (p.19). This reaction causes the sense of islamophobia in Updike's Terrorist: "IIn Islam, diat's called blasphemy, trying to usurp God's prerogative of creation.' 'Well, I know. That's why there aren't any statues or paintings in mosques. To me that seems unnecessarily bleak. God gave us eyes to see what, then?"' (p.134).

The concept of resistance refers to the suppressed minorities to regain their colonized identity. It indicates the colonized people continual struggle to affirm their original identity which is destructed by colonialism. Consequently, the concept of resistance has a contiguous relationship with identity. In the main, orientalism emphasizes the idea of original identity both before and after colonialism. The conceptualization of identity before colonialism exemplifies the suppressed people's struggle to maintain their inherited religion and traditions. However, colonialism devastates that struggle for the sake of exploiting the colonized people's lands. These lands abound with natural benefits 
that could reinforce the existence of the colonizers on the colonized people's faith (Hodgkins, 2002) Such quest for identity corresponds to the scenes of islamophobia in Updike's Terrorist:

"Not die next day but the next, a Friday, Charlie, sitting in the passenger seat, directs the truck to leave the lot and go right on Reagan, then left at the light up on Sixteenth down to West Main, into that section of New Prospect, extending some blocks west of the Islamic Center, where emigrants from the Middle East, Turks and Syrians and Kurds packed into steerage on the glamorous transatlantic liners, settled generations ago, when the silk-dyeing and leather-tanning plants were in full operation" (p.136).

Islamophobia, therefore, undergoes radical transformation by the hegemony of the West. When they suppress the colonized lands, they begin to spread their religious and cultural traditions. These might include language, religion, customs, traditions and so forth. Religion, for example is taught to the colonized people to persuade them to embrace the colonizers' religion. Religious conversion, in this sense, indicates the state of identity transformation. The original national religious sects would dissolve in the religious crucible of the colonizers. At this stage, the suppressed Muslims change according to the teachings and religious views of life (Hodgkins, 2002). The same thing could be traced in the case of language, customs and traditions. In Updike's Terrorist, Muslims change in order to oppose the West hegemony. Such opposition results in the sense of islamophobia:

Western-style suits, shapeless with daily wear, favored by the Mediterranean males, Sicilians and Greeks, who preceded them in this neighborhood of tight-to-the-street row houses. The younger Arab-Americans, idle and watchful, have adopted die bulky running shoes, droopy oversize jeans, and hooded sweatshirts of black homeys. Ahmad, in his prim white shirt and his black jeans slim as two stovepipes, would not fit in here. To these co-religionists, Islam is less a faith, a filigreed doorway into the supernatural, than a habit, a facet of their condition as an underclass, alien in a nation that persists in thinking of itself as light-skinned, English-speaking, and Christian. To Ahmad these blocks feel like an underworld he is timidly visiting, an outsider among outsiders. (p.136)
The concept of ambivalence is associated with different disciplines of the concept of islamophobia. It is also connected with the social representations among people at various global scales. The concept might connect one nation with another one based on similar universal issues and national affairs. The concept of ambivalence originated in the critical studies of the interconnectedness between one ethnicity with another one within the broad conceptualization of the concept. To put it simply, the concept of ambivalence includes the ways by which each nation perceives other nations in the world. Based on this perception, the concept of ambivalence comprises the many nations within one unified filed, like politics and ethnography. The typography could be considered as another aspect of the concept of ambivalence since there is a close affinity between the concept and the regional demarcations that unify ore divide different countries (Lewallen, 2016). Updike, in Terrorist, reveals the ambivalent relationship between the East and West by approaching the Muslims and non-Muslims in the plot. The sense of islamophobia emanates from this relationship: "'He is a faithful son of Islam,' Charlie tells him. 'We all envy him, right?' Again Ahmad feels irritation with Charlie, for acting proprietorial where he has no ownership. Only the doer owns this deed. Something preoccupied and bossy in Charlie's approach casts doubt on the absolute nature of istishhdd and the exalted, dread-filled condition of the istishhddi" (p.140).

The concept of ambivalence also involves the colonial insights of islamophobia. The co-existence between one nation and another depends on the ambivalence relationship (Ray 2015). That is, how each nation becomes accustomed to and familiar with the other country's customs and traditions. Here, colonialism comes into prominence. When any nation tries to colonize and subjugates other nation, the newly colonized nation is obliged to adapt and go along with the colonizer nation. This is because the colonizer country exerts hegemony and colonial power over the colonized nation in the same regional peripheries. As such, colonialism plays an integral role in defining the customs and traditions of the colonizers. Consequently, ambivalence could be defined as the relationship that governs those socio-political grounds between the occupied nation and its foreign colonizers (Ray 2015). Accordingly, the relationship might be asserted as that the colonized perceives and judges the other nation on the ground of colonialism and cultural traditions. In Updike's Terrorist, 
the ideological encounters between the West nation and the East nation produce islamophobia:

But most important," Shaikh Rashid urged, "is the Holy Qur'an. If your spirit were to weaken in the long night ahead of you, open it, and let the only God speak to you through His last, perfect prophet. Unbelievers marvel at the power of Islam; it flows from the voice of Mohammed, a manly voice, a voice from the desert and the marketplace - a man among us, who knew earthly life in all its possibilities and yet hearkened to a voice from beyond, and who submitted to its dictation though many in Mecca were quick to ridicule and revile him. (pp.151-52)

The colonial aspects of the concept of ambivalence depend on the colonial manifestations of islamophobia into colonial contexts, such as literature and political discourses. In this manner, the concept of ambivalence embodies the colonial circumferences that unify the common and discrepant political viewpoints in the world. The significance of the concept of ambivalence lies in its representation of colonialism in literary texts. Being so, it enables critics to argue that the concept of ambivalence could be applied to interpret and study many literary works. Moreover, it facilitates the understanding of politics and its practices which are depicted in literature, especially the literature that treats politics from colonial perspectives (Ray 2015). In Updike's Terrorist, the concept of ambivalence corresponds to the notion of islamophobia: "The uncle will talk, or somebody will. It's hard to believe one brother had no idea what the other was up to. These Arabs all pressure each other with Islam: how can you say no to the will of Allah?" (p.162). The novel's protagonist, Ahmad, conveys this notion since he refers to the victory of Islam over the West: "Ahmad reviews the unfolding, slithering fabric of what he has heard and concludes, 'It would be a glorious victory for Islam' ... 'Islam? How so?' 'It would slay and inconvenience many unbelievers"' (p.162).

In The Location of Culture, Homi Bhabha (1994) postulates the critical crux of colonial ambivalence. Bhabha is considered the predecessor of the concept of ambivalence in relation to pos-colonialism; and according to him, the concept of ambivalence is a "subject of a difference that is almost the same, but not quite" (p.122). The subject of difference, says Bhabha, is the racial variations between the colonizers and the colonized, but is "almost" the same in the sense that it does not divide them regardless their racial antecedents. Additionally, the concept is significant as it refers to "the unstable environment that the colonized [the black] is forced to either adapt to or work really hard to reject" (p.122). Islamophobia, in this regard, originates in the form of the ambivalent relationship between the East and West in Updike's Terrorist. Ahmad describes the West attitudes towards Islam which, in turn, refers to the spread of islamophobia: "It is one of the pagan West's grave errors, according to Islamic theorists, to make an idol of an animal function" (p.169).

\section{CONCLUSION}

In sum, the self-other relationship between the East and West, in Updike's Terrorist, represents the ideological encounter between Muslims and non-Muslims in the United States. On the one hand, Muslims try to get rid of their American Western hegemony. On the other hand, the American Western attitudes are mere nomenclature of the Islamic extreme perception of the west. In this context, these discrepant attitudes resulted in the ideological aversion between the two nations. Such aversion is the nexus of islamophobia discussed in the novel. Thus, the representations of islamophobia are the authentic replica of new orientalism portrayed in the narrative fabric of the novel.

\section{REFERENCES}

[1] Abu Jweid, A. (2016). The fall of national identity in Chinua Achebe's Things Fall Apart. PERTANIKA, 23(5), 529 - 540.

[2] Aulette, J. R. (2017). A global view of face and racism. New York: Oxford University Press.

[3] Bhabha, H. (1994). The location of culture. London: Routledge.

[4] Flores, J. (2000). From bomba to hip-hop: Puerto rican culture and Latino identity. New York: Columbia University Press.

[5] Hodgkins, C. (2002). Reforming empire: Protestant colonialism and conscience in British literature. Columbia: University of Missouri Press.

[6] Karlsen, C. F. (1987). The devil in the shape of a woman: Witchcraft in colonial new England. New York: Norton.

[7] Langfur, H. (2006). The forbidden lands: Colonial identity, frontier violence and the persistence of Brazil's Eastern Indians, 1750-1830. Stanford (Calif.: Stanford University Press.

[8] Lewallen, A. (2016). The fabric of indigeneity: Ainu identity, gender, and settler colonialism in Japan. Albuquerque: University of New Mexico Press. 
[9] Lucas, G. (2006). An archaeology of colonial identity: Power and material culture in the Dwars Valley, South Africa. Berlin: Springer.

[10] Paquet, S. P. (2002). Caribbean autobiography: Cultural identity and self-representation. Madison: University of Wisconsin Press.

[11] Ray, C. (2015). Crossing the color line: Race, sex, and the contested politics of colonialism in Ghana. Athens, Ohio: Ohio University Press.

[12] Said, E. (1979). Orientalism. New York: Vintage Books.

[13] Shaffer, J. (2007). Performing patriotism: National identity in the colonial and revolutionary American theater. Philadelphia: University of Pennsylvania Press.

[14] Sicherman, C. (1990). Ngugi Wa Thiong'o, the making of a rebel: A sourcebook in Kenyan literature and resistance. London: H. Zell Publishers.

[15] Sutphen, M. (2015). Medicine and colonial identity. London: Routledge.

[16] Updike, J. (2006). Terrorist. New York: Random House Trade Paperbacks. 